\title{
Infeksi Saluran Napas Akut pada Balita di Daerah Urban Jakarta
}

\author{
Kholisah Nasution*, M. Azharry Rully Sjahrullah*, Kartika Erida Brohet*, Krishna Adi \\ Wibisana*, M. Ramdhani Yassien*, Lenora Mohd. Ishak*, Liza Pratiwi*, Corrie Wawolumaja**, \\ Bernie Endyarni*** \\ * Sarjana Kedokteran Fakultas Kedokteran Universitas Indonesia \\ ** Departemen Ilmu Kedokteran Komunitas Fakultas Kedokteran Universitas Indonesia \\ *** Departemen Ilmu Kesehatan Anak Fakultas Kedokteran Universitas Indonesia/RS.Cipto Mangunkusumo, \\ Jakarta
}

Latar belakang. Infeksi saluran napas akut (ISPA) merupakan penyebab terpenting morbiditas dan mortalitas pada anak terutama usia 6-23 bulan. Beberapa faktor dianggap berhubungan dengan ISPA antara lain, jenis kelamin, usia balita, status gizi, imunisasi, berat lahir balita, suplementasi vitamin A, durasi pemberian ASI, pendidikan ibu, pendapatan keluarga, crowding, pajanan rokok, serta pengetahuan, sikap, dan perilaku ibu terhadap ISPA.

Tujuan. Mengetahui angka prevalensi ISPA pada balita di Rukun Warga (RW) 04 Pulo Gadung serta faktor-faktor yang berhubungan.

Metode. Penelitian potong lintang yang dilakukan pada 103 subjek menggunakan guided questionnaire yang valid dan reliable untuk mengetahui apakah terdapat diagnosis ISPA dalam satu bulan terakhir pada anak usia 6 bulan- 59 bulan serta faktor-faktor yang berhubungan, di RW 04 Kelurahan Pulo Gadung, Jakarta Timur, pada bulan Desember 2008.

Hasil. Prevalensi ISPA pada balita 40,8\%, didapatkan hubungan bermakna antara pajanan asap rokok $(p=0,006)$ dan riwayat imunisasi $(p=0,017)$ dengan prevalensi ISPA pada balita. Namun tidak didapatkan hubungan antara jenis kelamin, usia, status gizi subjek, tingkat pendidikan responden, pendapatan keluarga, crowding, jumlah rokok, suplementasi vitamin A, durasi ASI total dengan prevalensi ISPA pada balita.

Kesimpulan. Prevalensi ISPA pada balita cukup tinggi dan terdapat hubungan bermakna antara pajanan asap rokok dan riwayat imunisasi dengan prevalensi ISPA pada balita.(Sari Pediatri 2009;11(4):223-8).

Kata kunci: balita, ISPA, imunisasi, asap rokok

Alamat korespondensi

Dr. Bernie Endyarni, SpA. Divisi Tumbuh Kembang-Pediatri Sosial Departemen Ilmu Kesehatan Anak FKUI/RSCM. Jl. Salemba Raya No. 6 Jakarta 10430. Email : bernie.medise@yahoo.com
$\mathrm{I}$

nfeksi saluran napas akut (ISPA) merupakan penyebab terpenting morbiditas dan mortalitas pada anak. Kelompok usia 6-23 bulan adalah kelompok umur paling rentan untuk mengalami ISPA. ${ }^{1}$ Berdasarkan data WHO dan Departemen Kesehatan Republik Indonesia tahun 2008, pneumonia 
yang merupakan salah satu jenis ISPA adalah penyebab paling banyak kematian balita di dunia dan juga di Indonesia. ${ }^{2,3}$

Dari tahun ke tahun, prevalensi ISPA di Indonesia tetap tinggi, yaitu sekitar 21,6\% di daerah perkotaan. ${ }^{2}$ Hasil Survei Kesehatan Rumah Tangga (SKRT) menunjukkan jumlah balita penderita pneumonia menurun dari 804.937 pada tahun 1999 menjadi 479.283 pada tahun 2000. ${ }^{4}$ Namun dari tahun 2000 hingga 2003 jumlah balita penderita ISPA cenderung menetap di angka yang sama meski pemerintah telah mencanangkan program pemberantasan ISPA. ${ }^{3}$

Beberapa penelitian telah dilakukan untuk melihat faktor yang mempengaruhi tingginya prevalensi ISPA, di antaranya adalah penelitian Depkes RI pada tahun 2002. Penelitian tersebut menunjukkan bahwa faktor risiko yang berhubungan dengan prevalensi ISPA adalah gangguan asap dari pabrik dan lokasi rumah di daerah rawan banjir. Selain itu masih banyak faktor yang menurut kepustakaan berperan pada terjadinya ISPA, antara lain jenis kelamin, usia balita, status gizi, ${ }^{5,6}$ imunisasi, berat lahir balita, ${ }^{7}$ suplementasi vitamin $\mathrm{A},{ }^{8-10}$ durasi pemberian ASI, ${ }^{11-14}$ pendidikan ibu, ${ }^{15-16}$ pendapatan keluarga, ${ }^{15}$ crowding, pajanan rokok, ${ }^{17}$ serta pengetahuan, sikap, dan perilaku ibu terhadap ISPA. ${ }^{18-21}$ Berkaitan dengan hal tersebut, penelitian ini diadakan untuk mengetahui angka prevalensi ISPA pada balita di rukun warga (RW) 04 Pulo Gadung serta faktor-faktor yang berhubungan untuk mencari strategi yang tepat menurunkan angka kejadian ISPA dan pada akhirnya meningkatkan taraf kesehatan anak pada umumnya.

\section{Metode}

Penelitian deskriptif analitik dengan desain potong lintang yang dilakukan di RW 04 Kelurahan Pulo Gadung, Jakarta Timur pada Desember 2008. Sebelumnya dilakukan uji coba pengumpulan data dan validasi kuesioner di daerah yang sama. Sampel diambil secara purposive sampling dengan mengundang seluruh balita di RW 04 ke tempat penelitian hingga mencapai 103 balita.

Kriteria inklusi penelitian yaitu bayi berusia 6 bulan hingga 59 bulan dalam keluarga inti. Kriteria inklusi responden yaitu orangtua subjek atau pengasuhnya sejak lahir, bersedia diwawancara, dan memperbolehkan peneliti melakukan pengukuran antropometri pada subjek. Apabila subjek memiliki kelainan kongenital yang nyata, kelainan metabolik, penyakit kronis, defisiensi imun atau dalam pengobatan imunosupresan jangka panjang, tidak diikutsertakan dalam penelitian. Sampel dan responden yang memenuhi kriteria dikumpulkan untuk diwawancarai dan dilakukan pengukuran antropometri.

Diagnosis dan pengumpulan data dilakukan oleh para sarjana kedokteran dengan konsultan dokter anak.

Penelitian dilakukan setelah mendapat persetujuan dari setiap responden. Kriteria diagnosis ISPA ini berdasarkan atas tiga bagian, yaitu waktu sakit kurang dari 14 hari, tidak ada riwayat atopi, dan terdapat gejala ISPA baik non-pneumonia maupun pneumonia. Subjek tergolong pada ISPA non-pneumonia bila terdapat demam dan salah satu gejala yaitu pilek, hidung tersumbat, batuk kering, nyeri tenggorok, suara serak, stridor, batuk berdahak, napas cepat, mengi, dan keluar cairan telinga. Sedangkan subjek digolongkan dalam ISPA pneumonia jika terdapat demam, batuk berdahak, dan sesak napas. Bila terdapat subjek yang menderita ISPA pada saat pengambilan data, subjek akan dirujuk ke Puskesmas Pulogadung.

Selain mendiagnosis ISPA dalam sebulan terakhir, juga ditanyakan faktor-faktor yang berhubungan dengan ISPA yaitu jenis kelamin, usia, tingkat pendidikan, status gizi subjek, tingkat pendapatan keluarga, crowding, pemberian ASI, pajanan asap rokok dan jumlah pajanan asap rokok, suplementasi vitamin A, berat lahir, riwayat imunisasi, serta pengetahuan, sikap, dan perilaku orangtua mengenai ISPA dengan menggunakan kuesioner yang valid dan reliable.

\section{Hasil}

Prevalensi riwayat ISPA satu bulan terakhir pada 103 balita di RW 04 Kelurahan Pulo Gadung 40,8\% dengan jenis ISPA terbanyak non-pneumonia $(97,6 \%)$. Adapun gejala ISPA non-pneumonia yang paling sering terjadi ini adalah pilek $(87,8 \%)$ dan batuk kering $(71,4 \%)$.

Jenis kelamin hampir seimbang antara laki-laki dan perempuan 51,5\% dengan jumlah batita 45,6\%. Sebagian besar subjek memiliki status gizi kurang (56,3\%), terpapar asap rokok 1-20 batang di rumah setiap hari (66\%), mendapatkan suplementasi vitamin A secara rutin (76\%), dan hanya 6,8\% subjek yang tidak pernah mendapat suplementasi vitamin A (Tabel 1). 
Tingkat pendidikan dan status ekonomi responden di RW 04 yang tergolong rendah, berjumlah masingmasing 67 dan 53 dari 103 responden (Tabel 2).

Tabel 1. Karakteristik demografi subjek $(\mathrm{n}=103)$

\begin{tabular}{llcc}
\hline Variabel & Kategori & Frekuensi & $\%$ \\
\hline Jenis kelamin & Laki-laki & 53 & 51,5 \\
& Perempuan & 50 & 48,5 \\
Usia (bulan) & Bayi (6-12) & 19 & 18,4 \\
& Batita (13-36) & 47 & 45,6 \\
& Balita (37-59) & 37 & 35,9 \\
Status gizi & Kurang & 58 & 56,3 \\
& Cukup & 38 & 36,9 \\
& Lebih & 7 & 6,8 \\
Suplementasi & Ya, rutin & 81 & 78,6 \\
vitamin A & Ya, tidak rutin & 15 & 14,6 \\
& Tidak & 7 & 6,8 \\
Berat lahir & Berat lahir normal & 95 & 92,2 \\
& Berat lahir rendah & 8 & 7,8 \\
Riwayat & Imunisasi lengkap & 61 & 59,2 \\
imunisasi & Imunisasi tidak lengkap & 40 & 38,8 \\
& Tidak mendapat imunisasi & 2 & 1,9 \\
\hline
\end{tabular}

Tabel 2. Karakteristik pendidikan dan status ekonomi $(\mathrm{n}=103)$

\begin{tabular}{llcc}
\hline Variabel & Kategori & Frekuensi & $\%$ \\
\hline Tingkat pendidikan & Rendah & 67 & 65,0 \\
& Menengah & 34 & 33,0 \\
Pendapatan keluarga & Tinggi & 2 & 1,9 \\
& Rendah & 53 & 51,5 \\
& Menengah rendah & 45 & 43,7 \\
& Menengah tinggi & 5 & 4,9 \\
Crowding & Tinggi & 0 & 0 \\
& Tidak ideal & 83 & 80,6 \\
Pajanan asap rokok & Ideal & 20 & 19,4 \\
& Tidak & 24 & 23,3 \\
Jumlah pajanan rokok & Tidak ada & 79 & 76,7 \\
& 1-20 batang & 24 & 23,3 \\
Pengetahuan & Baik batang & 11 & 66,0 \\
& Cukup & 44 & 42,7 \\
\multirow{5}{*}{ Sikap } & Kurang & 46 & 44,7 \\
& Baik & 13 & 12,6 \\
Perilaku & Cukup & 44 & 52,4 \\
& Kurang & 5 & 42,7 \\
& Risiko rendah & 38 & 36,9 \\
& Risiko sedang & 47 & 45,6 \\
& Risiko tinggi & 18 & 17,5 \\
\hline
\end{tabular}

Pada analisis statistik, variabel berat lahir menggunakan uji statistik Fisher sedangkan variabel lainnya menggunakan uji chi-square. Berdasarkan uji statistik, tidak didapatkan hubungan bermakna antara jenis kelamin, usia, status gizi subjek, pendapatan keluarga, crowding, jumlah rokok, dan suplementasi vitamin A dengan kejadian ISPA pada balita. Sementara itu, terdapat hubungan bermakna antara tingkat pendidikan responden, ada tidaknya pajanan asap rokok, dan riwayat imunisasi dengan kejadian ISPA pada balita. Hubungan antara durasi ASI, yang merupakan variabel numerik, dengan kejadian ISPA diolah dengan menggunakan uji Mann-Whitney. Menurut uji Mann-Whitney tidak didapatkan hubungan bermakna antara durasi ASI total dengan kejadian ISPA (Tabel 3).

\section{Diskusi}

Subjek pada penelitian kami dapat mewakili keadaan masyarakat urban, serta metode pengumpulan data dengan purposive sampling mudah dilakukan dan lebih menghasilkan ketepatan data jika dibandingkan dengan metode sampel acak sederhana. Adapun kekurangan penelitian ini adalah penggunaan kuesioner yang dibacakan kepada responden (guided questionnaire) yang dapat menimbulkan bias karena data yang dikumpulkan sangat tergantung pada daya ingat responden dan pemahaman bahasa responden.

\section{Prevalensi ISPA}

Prevalensi ISPA 40,8\%, lebih rendah dibandingkan dengan penelitian Napitupulu $\mathrm{dkk}^{22}$ pada daerah urban Jakarta lain yakni 66,2\%. Penelitian Litbangkes Depkes RI yakni $21,6 \%{ }^{3}$ menggunakan balita dari seluruh Indonesia. Jenis ISPA terbanyak ialah nonpneumonia $(97,6 \%)$, dan sesuai dengan penelitian Napitupulu dkk $(90,7 \%),{ }^{22}$ dan gejala yang paling sering ditemukan adalah pilek $(87,8 \%)$ dan batuk kering $(71,4 \%)$. Penelitian Sikolia dkk ${ }^{16}$ mendapatkan gejala demam, pilek, dan batuk sebagai gejala ISPA tersering pada balita.

Menurut Fuchs $\mathrm{dkk}^{17}$ terdapat peningkatan frekuensi terjadinya ISPA yang signifikan pada usia $24-35$ bulan yaitu $66 \%$. Kami mendapatkan proporsi ISPA pada batita $47,6 \%$ dan bayi $52 \%$ dari jumlah batita dan bayi yang diteliti. Hal tersebut menunjukkan 
Tabel 3. Faktor risiko pada kejadian ISPA $(\mathrm{n}=103)$

\begin{tabular}{|c|c|c|c|c|}
\hline \multirow{2}{*}{ Variabel } & \multirow{2}{*}{ Kategori } & \multicolumn{2}{|c|}{ Kejadian ISPA, n (\%) } & \multirow{2}{*}{ Nilai ${ }_{F}$} \\
\hline & & Tidak & $\mathrm{Ya}$ & \\
\hline \multirow[t]{2}{*}{ Jenis kelamin } & Laki-laki & $33(54,1)$ & $17(40,5)$ & 0,174 \\
\hline & Perempuan & $28(45,9)$ & $25(59,5)$ & \\
\hline \multirow[t]{3}{*}{ Usia } & Balita & $25(41,0)$ & $12(28,6)$ & 0,327 \\
\hline & Batita & $27(44,3)$ & $20(47,6)$ & \\
\hline & Bayi & $9(14,8)$ & $10(23,8)$ & \\
\hline \multirow[t]{2}{*}{ Tingkat pendidikan } & Tinggi & $25(40,9)$ & $11(26,2)$ & 0,122 \\
\hline & Rendah & $36(59,1)$ & $31(73,8)$ & \\
\hline \multirow[t]{2}{*}{ Pendapatan keluarga } & Menengah-Tinggi & $31(50,8)$ & $18(42,9)$ & 0,427 \\
\hline & Rendah & $30(49,2)$ & $24(57,1)$ & \\
\hline \multirow[t]{2}{*}{ Status gizi } & Cukup-Lebih & $27(44,3)$ & $16(40,0)$ & 0,672 \\
\hline & Kurang & $34(55,7)$ & $24(60,0)$ & \\
\hline \multirow[t]{2}{*}{ Crowding } & Ideal & $14(23)$ & $6(14,3)$ & 0,275 \\
\hline & Tidak Ideal & $47(77,0)$ & $36(85,7)$ & \\
\hline \multirow[t]{2}{*}{ Pajanan asap rokok } & Ya & $41(67,2)$ & $38(90,5)$ & 0,006 \\
\hline & Tidak & $20(32,8)$ & $4(9,5)$ & \\
\hline \multirow[t]{3}{*}{ Jumlah rokok (batang) } & Tidak ada & $19(31,1)$ & $5(11,9)$ & 0,076 \\
\hline & $1-20$ & $36(59)$ & $32(76,2)$ & \\
\hline & $21-60$ & $6(9,8)$ & $5(11,9)$ & \\
\hline \multirow{2}{*}{ Suplementasi vitamin A } & Ya & $51(83,6)$ & $30(71,4)$ & 0,138 \\
\hline & Tidak & $10(16,4)$ & $12(28,6)$ & \\
\hline \multirow[t]{2}{*}{ Berat lahir } & Normal & $55(90,2)$ & $40(95,2)$ & 0,467 \\
\hline & Rendah & $6(9,8)$ & $2(4,8)$ & \\
\hline \multirow[t]{2}{*}{ Riwayat imunisasi } & Lengkap & $42(68,9)$ & $19(45,2)$ & 0,017 \\
\hline & Tidak lengkap & $19(31,1)$ & $23(54,8)$ & \\
\hline \multirow[t]{3}{*}{ Pengetahuan } & Baik & $25(41,0)$ & $19(45,2)$ & 0,764 \\
\hline & Cukup & $29(47,5)$ & $17(40,5)$ & \\
\hline & Kurang & $7(11,5)$ & $6(14,3)$ & \\
\hline \multirow[t]{2}{*}{ Sikap } & Baik & $28(45,9)$ & $26(61,9)$ & 0,110 \\
\hline & Cukup-Kurang & $33(54,1)$ & $16(38,1)$ & \\
\hline \multirow[t]{3}{*}{ Perilaku } & Risiko rendah & $26(42,6)$ & $12(28,6)$ & 0,265 \\
\hline & Risiko sedang & $24(39,3)$ & $23(54,8)$ & \\
\hline & Risiko tinggi & $11(18,0)$ & $7(16,7)$ & \\
\hline Durasi ASI total & & & & 0,497 \\
\hline
\end{tabular}

usia yang lebih muda rentan terkena infeksi. ${ }^{1}$

Hubungan antara tingkat pendidikan responden dengan prevalensi ISPA dilaporkan oleh PawlinskaChmara, ${ }^{23}$ Savitha, ${ }^{7}$ dan Macedo. ${ }^{15}$ Kami jumpai, jumlah balita yang tidak menderita ISPA mencapai lebih dari dua kali lipat jumlah balita yang menderita ISPA pada kelompok balita dengan orangtua yang berpendidikan menengah tinggi.

Savitha $\mathrm{dkk}^{7}$ menyatakan bahwakeadaan malnutrisi berpengaruh pada proporsi ISPA pada balita. Namun penelitian Savitha tidak memperhatikan keadaan status gizi lain dan penelitiannya hanya berkaitan dengan ISPA bagian bawah. Selain itu, pada penelitian Arsyad ${ }^{8}$ di daerah pedesaan menyatakan bahwa status gizi berhubungan dengan kejadian ISPA pada balita. Pada penelitian kami dijumpai balita yang mengalami ISPA lebih banyak dengan gizi kurang dibandingkan pada balita dengan gizi cukup atau lebih.

Penelitian Savitha ${ }^{7}$ dan Macedo ${ }^{15}$ menunjukkan bahwa faktor pendapatan keluarga merupakan salah satu faktor yang memiliki hubungan bermakna terhadap kejadian ISPA pada balita. Sedangkan 
proporsi ISPA pada penelitian kami menunjukkan lebih banyak terjadi pada balita dengan pendapatan keluarga yang rendah.

Dalam penelitian lain, dilaporkan hubungan crowding dengan prevalensi ISPA. Sikolia $\mathrm{dkk}^{16}$ mendefinisikan crowding adalah jumlah orang yang tinggal di dalam rumah tanpa menghiraukan berapa luas rumah tersebut. Sedangkan pada Cardoso dkk ${ }^{16}$ menyatakan jumlah orang yang tidur di kamar balita tersebut. Pada penelitian ini proporsi ISPA pada crowding yang tidak ideal lebih banyak dibandingkan crowding yang ideal

Hubungan pajanan asap rokok dengan kejadian ISPA, sejalan dengan laporan Gutierrez-Ramirez dkk ${ }^{14}$ bahwa balita yang berada di dalam lingkungan dengan asap rokok memiliki kemungkinan pneumonia lebih tinggi. Beberapa penelitian sebelumnya mendapatkan bahwa hubungan suplementasi vitamin A dengan prevalensi ISPA belum jelas. Namun demikian, proporsi balita yang rutin mendapatkan suplementasi vitamin A lebih sedikit terjadinya ISPA dibandingkan balita yang tidak rutin mendapatkan suplementasi vitamin A. Penelitian Anders Koch $\mathrm{dkk}^{24}$ mendapatkan bahwa berat lahir tidak mempengaruhi angka kejadian ISPA.

Terdapat hubungan antara imunisasi dengan prevalensi ISPA, sejalan dengan penelitian Savitha $\mathrm{dkk}^{7}$ yang menyebutkan imunisasi tidak lengkap sebagai faktor risiko bermakna kejadian ISPA. Deb $\mathrm{dkk}^{25}$ melaporkan bahwa anak yang tidak mendapat imunisasi memiliki risiko 2,7 kali untuk mengalami ISPA. Wantani ${ }^{1}$ menyebutkan campak, pertusis, dan beberapa penyakit lain dapat meningkatkan risiko terkena ISPA dan penyakit-penyakit tersebut dapat dicegah dengan imunisasi.

Secara umum, pengetahuan responden dikategorikan cukup. Dari sebaran pengetahuan yang diperoleh, didapatkan bahwa pengetahuan mengenai pencegahan ISPA yang terpenting yaitu memberikan ASI yang masih rendah $(27,2 \%)$. Sebagian besar responden dalam penelitian ini memiliki sikap yang baik tentang ISPA pada balita. Namun sikap orangtua atau pengasuh tentang etiologi dan faktor risiko ISPA yang masih kurang, akan mempengaruhi perilaku dalam penanganan dan pencegahan. Perilaku berisiko sedang ini menggambarkan perilaku pencegahan yang masih kurang baik.

Durasi pemberian ASI dengan prevalensi ISPA. dilaporkan oleh Mardya Lopez-Alarco $\mathrm{dkk}^{11}$ yang menunjukkan hubungan terbalik antara durasi ASI eksklusif dengan prevalensi ISPA. Wantania ${ }^{1}$ juga menyebutkan pemberian ASI mempunyai pengaruh proteksi terhadap ISPA selama setahun pertama. Namun untuk penelitian ini perlu diingat bahwa dengan bertambahnya usia balita, kadar imunoglobulin pada ASI pun akan berkurang, sehingga bila pemberian ASI diberikan lebih lama tidak terlalu berpengaruh pada ketahanan tubuhnya mengatasi mikroorganisme penyebab ISPA. ${ }^{25}$

\section{Kesimpulan}

Prevalensi ISPA pada penelitian kami 40,8\%. Faktorfaktor yang memiliki hubungan secara statistik dengan prevalensi ISPA adalah pajanan asap rokok dan riwayat imunisasi. Sedangkan jenis kelamin, usia, dan status gizi subjek, serta tingkat pendidikan responden, pendapatan keluarga, crowding, jumlah rokok, suplementasi vitamin A, dan durasi ASI total tidak berhubungan dengan prevalensi ISPA. Disarankan dokter Puskesmas, rumah sakit, dan para dokter praktek swasta sebaiknya melakukan pembenahan perilaku orangtua terhadap ISPA, menyarankan orang tua untuk tidak merokok, dan melengkapi lima imunisasi dasar sebelum usia 1 tahun.

\section{Daftar Pustaka}

1. Wantania JM, Naning R, Wahani A. Infeksi saluran pernapasan akut. Dalam: Rahayoe NN, Supriyatno B, Setiyanto DB, penyunting. Buku Ajar Respirologi Anak. Edisi Pertama. Jakarta: Pusat Penerbitan Ikatan Dokter Anak Indonesia; 2008.h.286-7.

2. Sub Direktorat Infeksi Saluran Pernapasan Akut (ISPA). Buku saku pneumonia balita. Jakarta: Departemen Kesehatan. 2007.h.1.

3. Departemen Kesehatan Republik Indonesia. Profil kesehatan Indonesia 2003. Diunduh dari : http://bankdata. depkes.go.id/data\%20intranet/ProfilKes/2003/Profil2003.pdf. Diakses tanggal 25 November 2008.

4. Badan Litbang Kesehatan Republik Indonesia. Hubungan faktor lingkungan dan sosial ekonomi dengan morbiditas (Keluhan ISPA dan Diare). Diunduh dari http:// digilib.litbang.depkes.go.id/go.php?id=jkpkbppk-gdl-res2003-muluki2c-2040-ispa\&q=ispa. Diakses tanggal 25 November 2008. 
5. Long KZ, Montoya Y, Hertzmark E, Santos JI. A doubleblind, randomized, clinical trial of the effect of vitamin $A$ and zinc supplementation on diarrheal disease and respiratory tract infections in children in Mexico City, Mexico. Am J Clin Nutr 2006;83:693-700.

6. Heird WC. Food insecurity, hunger and undernutrition. Dalam: Behrman RE, Kliegman RM, Jenson HB, penyunting. Nelson Textbook of Pediatrics,. Edisi ke-17. Philadelphia: Saunders; 2004.h.1701.

7. Savitha MR, Nandeeshwara SB, Kumar MJP,. Modifiable risk factors for acute lower respiratory tract infestions. Indian J Pediatr 2007;74:477-82.

8. Arsyad T. Faktor determinan kejadian infeksi saluran pernapasan akut anak balita di kecamatan Bantimurung kabupaten Maros. Badan Penelitian dan Pengembangan Kesehatan Departemen Kesehatan, 2000.

9. Muluki M. Analisis faktor risiko yang berhubungan dengan terjadinya penyakit ISPA di Puskesmas Palanro Kecamatan Mallusetasi Kabupaten Barru Tahun 20022003. Badan Penelitian dan Pengembangan Kesehatan Departemen Kesehatan, 2003.

10. Susie S. Pola penyakit anak balita penderita gizi buruk. Center for Research and Development of Nutrition and Food, NIHRD, 2001.

11. Chantry CJ, Howard CR, Auinger P. Full breastfeeding duration and associated decrease in respiratory tract infection in US children. Pediatrics 2006;117:425-32.

12. Quigley MA, Kelly YJ, Sacker A. Breastfeeding and hospitalization for diarrheal and respiratory infection in the United Kingdom: millennium cohort study. Pediatrics 2007;119:e837-42.

13. Guetirrez-Ramirez SF, Molina-Salinas GM, GarciaGuerra JF, dkk. Enviromental tobacco smoke and pneumonia in children living in Monterrey, Mexico. Rev salud publica. 2007 [sitasi 26 November 2008];9:76-85. Diunduh dari: http://www.scielosp.org/pdf/rsap/v9n1/ v9n1a08.pdf.

14. Pereira EDB, Torres L, Macedo J. Effects of environmental smoke on lower respiratory system of children under 5 years old. Rev Saude Publica. 2000 [sitasi 26 November 2008];34:39-43. Diunduh dari http:// www.scielosp.org/ pdflrsplv34n1/1379.pdf.
15. Macedo SEC, Menezes AMB, Albernaz E. Risk factors for acute respiratory disease hospitalization in children under one year age. Rev Saude Publica 2007;41:351-8.

16. Sikolia DN, Mwololo K, Cherop H. The prevalence of acute respiratory infections and the associated risk factors: a study of children under five years of age in Kibera Lindi Village, Nairobi, Kenya. J Natl Inst Public Health 2002;51:67-72.

17. Siritantikorn S, Puthavathana P, Suwanjutha S. Acute viral lower respiratory infections in children in a rural community in Thailand. J Med Assoc Thai 2002;85(Suppl 4):S1167-75.

18. Chan GC, Tang SF. Parental knowledge, attitudes, antibiotic use for acute upper respiratory infection in children attending a primary healthcare clinic in Malaysia. Singapore Med J 2006;47:267-70.

19. Onta M. Knowledge, home care practice, and health seeking behavior of mothers regarding ARI. Journal of Nursing Education of Nepal 2003;5:50-5.

20. Kauchali S, Rollins N, Bland R. Maternal perceptions of acute respiratory infections in children under 5 in rural South Africa. Blackwell Pub 004;9:644-50.

21. Rashid SF, Hadi A, Afsana K. Acute respiratory infections in rural Bangladesh: cultural understandings, practices and the role of mothers and community health volunteers. Blackwell Pub 2001;6:249-55.

22. Napitupulu D, Nuryadin A, Hikmawati P. Prevalensi ISPA pada balita serta faktor-faktor yang berhubungan di RW 02 Kelurahan Rawasari Jakarta Pusat, Maret 2004. Tugas Program Kepaniteraan Ilmu Kesehatan Masyarakat Junior Fakultas Kedokteran UPN Veteran Jakarta, Maret 2004.

23. Pawlinska-Chmara R, Wronka I. Assessment of the effect of socioeconomic factors on the prevalence of respiratory disorders in children. J Physiol Pharm 2007;58:523-9.

24. Anders K, Kare M, Preben H. Risk factors for acute respiratory tract infections in young Greenlandic children. Am J Epidemiol 2003;158:374-384.

25. Deb SK. Acute respiratory disease survey in Tripura in case of children below five years of age. J Indian Med Assoc 1998;96:111-6. 